\title{
The Fourth ElementTargeting hypothesis of Alzheimer's disease pathogenesis and pathophysiology
}

\author{
Rodrigo O. Kuljiš* \\ The Brain-Mind Project, Inc. and Encephalogistics, Inc., Galveston, TX, USA
}

\section{Edited by:}

Facundo F. Manes, Favaloro University,

Argentina

\section{Reviewed by:}

Paulo Caramelli, Federal University of

Minas Gerais, Brazil

Leonel E. Rojo, Rutgers University, USA

\section{*Correspondence:}

Rodrigo O. Kuljiš, The Brain-Mind

Project, Inc. and Encephalogistics, Inc., 17 Compass Circle, Galveston, TX 77554-2919, USA.

e-mail:rodrigo.kuljis@gmail.com
Despite well over a century of research on all forms of the disorder known as Alzheimer's disease (AD), it is still not known whether the condition targets initially neurons, glial cells, other cellular elements in the brain, or components of cells, such as synapses, or molecules independently of their cellular compartmentalization, or otherwise (e.g., specific neuronal circuits). Multiple lines of highly suggestive but as yet insufficient experimental evidence are discussed here to formulate the hypothesis that AD results from primary (i.e., direct and initial) or secondary targeting of what we designate as the Fourth Element Cell (4EC): a relatively recently identified type of brain cell that exhibits features in common with neurons (e.g., synapses, participation in glutamatergic, and GABAergic neurotransmission), astrocytes, oligodendrocytes, and their precursors, but is in other respects clearly distinct from all of them. The 4EC is proposed to be the main target of both: (1) converging insults (i.e., not true "causes") that over time cause sporadic forms of AD as postulated by the Danger Signal Hypothesis - which was not formulated with 4EC in mind - as well as (2) the causes of inherited (i.e., familial) forms of neurodegeneration that resemble certain aspects of the clinical manifestations of sporadic AD.

Keywords: polydendrocyte, beta astrocyte, $\beta$ astrocyte, neuroglia, Alzheimer's disease, neurodegeneration, microglia, dementia

\section{INTRODUCTION}

The "sporadic" (i.e., non-familial) form of the Alzheimer's disease (AD) syndrome (sADs, where the first "s" is for "sporadic," and the second " $s$ " is for "syndrome") is by far the most common form of this disorder, and appears to result from a more or less individually unique set of converging risk factors, inadequately counterbalanced by a set of hypothetical protective factors that is also relatively unique to the individual affected (Fernández et al., 2008; Kuljiš, 2009a, 2010b). Here we postulate that these sets of opposing factors operate over decades - primarily (i.e., pathogenically) or secondarily (i.e., as a "common final pathway" of prior events) - to target the so-called "polydendrocytes," a.k.a. beta astrocytes and the "fourth neuroglial type," a relatively recently discovered (Reyners et al., 1982, 1986) and subsequently confirmed type of neural cell (Peters, 2004; Nishiyama et al., 2009; Bergles et al., 2010). We designate them here as the "Fourth Element" cell (4EC) following the tradition established by Santiago Ramón y Cajal when he made a distinction between neurons, macroglia, and all other types of cells in the brain, and lumped the latter types of cell into a "Third Element." Pío del Río Hortega subsequently discovered - and named - what we know today as the microglia from among the Third Element, employing a battery of silver carbonate impregnation methods. Modern technology has confirmed del Río Hortega's discoveries, and demonstrated that altered forms of microglia participate in the pathology of $\mathrm{AD}$, since they are a key component of senile plaques (Peress et al., 1993; Rogers et al., 2007; Leung et al., 2009; Streit et al., 2009) and other lesions (Streit et al., 2009).

In the present formulation, we propose that virtually all forms of the $\mathrm{AD}$ syndrome (ADs) result from targeting of the $4 \mathrm{EC}$, whether it is the primary (i.e., initial event) or a secondary insult resulting from either single causes of the sADs (i.e., the very rare, so-called "familial AD" that shares some of the phenotypes of the sADs, and quite often has clinical manifestations that are atypical for SADs), or the proposed converging set of risk vs. protective factors that appear to be by far the most common precipitating events leading to $\mathrm{AD}$ (Fernández et al., 2008; Kuljiš, 2009a,b, 2010a,b). This is relevant to a current, unresolved debate as to whether the primarily targeted element(s) in AD are neurons (Wirths et al., 2004; Bayer and Wirths, 2010), astrocytes (Selinfreund et al., 1991; Marshak et al., 1992; Sheng et al., 1994; Morgan et al., 1997; Johnstone et al., 1999; Naegele et al., 2003; Wyss-Coray et al., 2003; Kashon et al., 2004; Pertusa et al., 2007; Simpson et al., 2010), or microglia (Rogers et al., 2007; Fernández et al., 2008; Leung et al., 2009; Streit et al., 2009; Ager et al., 2010; Eikelenboom et al., 2010), and the overarching concern as to whether the postulated - and not mutually excluding - roles of nucleic acid damage (Gleckman et al., 1999; Myung et al., 2008), inflammation (Sastre et al., 2006; Rogers et al., 2007; Rojo et al., 2009; Eikelenboom et al., 2010; Heneka et al., 2010) and oxidative stress (Nunomura et al., 2006a,b; Myung et al., 2008) that are strongly felt to be central to the disease process target specific brain regions and circuits (Kuljiš, 2009b, 2010b), and/or cell types (as stated above, loc.cit.), and/or components of cells - such as synapses (De Kosky and Scheff, 1990; Terry et al., 1991; Bell and Cuello, 2006; Arendt, 2009) - rather than any of the former elements of the brain, or, instead, specific molecules regardless of which cellular and subcellular components or compartments they are situated in, even outside the brain. The recent finding that pancreatic lesions grossly resembling those in the brain occur in $\mathrm{AD}$ (Miklossy et al., 2010) can in fact support the latter possibility, or, alternatively, when considering the similarities between neurons and pancreatic beta 
cells, the former cell-based explanations. This unresolved debate is thus central to the elucidation of the key mechanisms underlying $\mathrm{AD}$, as well as to additional, urgent public health issues such as the controversy about the potentially common mechanisms underlying the converging epidemics of diabetes and dementia worldwide (Kuljiš and Šalković-Petrišić, 2010).

The present hypothesis is based on: (1) the evidence for glial participation in the pathophysiology of AD shown by Alzheimer (1906, 1907), and confirmed repeatedly ever since (Perusini, 1910, 1911; Beach et al., 1989; Peress et al., 1993; Sheng et al., 1994; Simpson et al., 2010), since 4EC are considered by most as glial cells (loc.cit), (2) a revision of the Danger Signals Hypothesis of AD pathogenesis (Fernández et al., 2008) which, makes use of the massive convergent evidence for susceptibility and protective factors that appear to operate over decades to eventually produce $\mathrm{AD}$, but that originally had no significant role for the increasingly apparent macroglial involvement in this condition (summarized in the paragraph above, and discussed in more detail below), and (3) the experimentally unasserted involvement of the $4 \mathrm{EC}$ in $\mathrm{AD}$, which is very likely because of their demonstrated hypersensitivity to DNA damage (Reyners et al., 1982, 1986) which is know to occur in AD (Gleckman et al., 1999; Myung et al., 2008) but had not been linked yet to the involvement of 4EC hypothesized here. This is consistent with the fact that DNA damage has already been identified in closely related neurodegenerative disorders (Gleckman et al., 1999) making our hypothesis plausibile. Furthermore, addressing this possibility in $\mathrm{AD}$ - but not considering the potential involvement of $4 \mathrm{EC}$ often confused with astrocytes - Myung et al. (2008) speculated that “...While the exact effect of the astrocytic DNA damage on the functions and vitality of astrocytes is unclear, the presence of DNA damage alone may not signify apoptosis but more likely identifies a subset of vulnerable astrocytes in which mechanisms of both cell death and repair have been activated..." (the emphasis is ours). This obviously opens the possibility that at least part of the astrocyte-like population susceptible to DNA damage in $\mathrm{AD}$ are $4 \mathrm{EC}$ (i.e., those first recognized by Reyners et al., as described in the next subsection), rather than true astrocytes.

\section{AN OVERVIEW OF THE DISCOVERY AND CHARACTERIZATION OF 4EC}

In a set of two studies that have received surprisingly little attention, Reyners et al. (1982, 1986) described their discovery of a large population of "unconventional" cells, that they felt erroneously is a previously unidentified astrocyte, that differs from the classically defined neuroglia in that: (1) they are antigenically different from astrocytes, oligodendrocytes and microglial cells, (2) express NG2 chondroitin sulfate proteoglycan-like immunoreactivity, (3) have no cytoplasmic intermediate filaments (e.g., GFAP, vimentin, and S100 protein), and exhibit a variety of ultra structural features different from astrocytes although they superficially resemble astrocytes (discussed below), (4) they cannot be labeled with markers for microglia, although they do express mRNA encoding proteolipid protein and myelin basic protein, (5) some of these cells appear to be oligodendrocyte progenitors and lose the NG2-like immunoreactivity as they mature, (6) they do not react with antibodies that recognize neurons, and (7) are more radiosensitive than conventional glial cells, which we presume may reflect their susceptibility to DNA damage and/or free radical toxicity, or both, since there are far more mitotically active than all other types of glial cells. These unusual properties were summarized by Peters (2004) in an elegant study of their ultrastructurally unique characteristics. 4 EC cells, which he dubbed the $\beta$ neuroglial cells, have pale, irregularly shaped nuclei with a thin rim of heterochromatin under the nucleolemma and a pale cytoplasm. These cells are common in the brain of rodents and non-human primates, including the cerebral neocortex and hippocampus known to be targeted in AD (Kuljišs, 2009a,b, 2010b). In monkeys, there are at least two types of Peters' $\beta$ neuroglial cells (a.k.a. "NG2 cells"), one with a darker nucleus than the more abundant type containing a lighter nucleus (Peters, 2004), suggesting that there may be various types of cell within the broad category of 4EC. While it is clear that the 4EC are neither conventional microglia nor oligodendrocytes, it is very easy to confuse them with astrocytes due to their superficial resemblance to the latter (Reyners et al., 1982,1986). However, 4EC are said to differ from astrocytes not only in the absence of intermediate filaments characteristic of the latter, but, as mentioned, in that they have a more irregularly shaped nucleus, a more regularly shaped cell body than protoplasmic astrocytes, and their mitochondria are thinner that those in astrocytes. Furthermore, 4EC are separated from the basal lamina of cerebral microvessels by intervening processes of astrocytes (Peters, 2004).

It is not known whether or how 4EC are involved in neurodegenerative disorders, whether $\mathrm{AD}$ or other conditions, such as Multiple Sclerosis - which is intriguing due to their suspected role as precursors of oligodendrocytes among other cell lineages, including possibly even neurons (Nishiyama et al., 2009).

\section{EC ARE THE RECIPIENTS OF NEURON-GLIA SYNAPSES}

Perhaps the most intriguing feature about $4 \mathrm{EC}$ is that they are the cells first identified by Bergles et al. (2000) as a type of glia receiving glutamatergic input from hippocampal pyramidal cells (known to be targeted in AD) and by inhibitory interneurons (also targeted in AD). In fact, both in the gray and white matter, there is an NG2-expressing glial cell that express also ionotropic receptors for glutamate and $\mathrm{GABA}_{\mathrm{A}}$ and have direct synaptic junctions with axons that enable the transient activation of these receptors. Furthermore, these exhibit all the features of "classical" neuron-to-neuron synapses including rapid activation, quantized responses, depression and facilitation and presynaptic inhibition (Nishiyama et al., 2009; Bergles et al., 2010). NG2-containing cells also express AMPA receptors, exhibit permeability to calcium, and express also NMDA receptors which raises the likelihood that they may be susceptible to excitotoxic injury. It is therefore highly plausible that this novel mechanism for neuron-glia signaling is important not only for the normal brain, but also relevant for the diseased central nervous system (Bergles et al., 2010) although, to the best of our knowledge, they have never been implicated in $\mathrm{AD}$. This is undoubtedly due mainly to the lack of awareness of the existence of the 4EC. However, among other possibilities, the targeting of $4 \mathrm{EC}$ we postulate may underlie the observed reduction in excitatory amino acid transporters that correlates with $\mathrm{AD}$ clinical manifestations, which has been attributed so far only to astrocyte damage, but not to 4EC degeneration (Simpson et al., 2010). 


\section{CAVEATS ON A CELLULAR-LEVEL FORMULATION}

Given the ongoing dramatic changes in the distinction between neurons and glial cells in the brain, the proposal that $4 \mathrm{EC}$ are pivotally involved in $\mathrm{AD}$ defies the former notion that the targeted element(s) can be conceptualized simplistically as neurons vs. macroglia vs. microglia, vs. other cells that are not of a neural lineage. In fact, considering the still unresolved nature of $4 \mathrm{EC}$ as precursors or variants of oligodendrocytes, their near-neuronal attributes (e.g., synapses and the participation on glutamatergic and GABAergic neurotransmission) and their features in common with "conventional" astrocytes, their postulated primary, even pathogenic, involvement in $\mathrm{AD}$ blurs the distinction among all conventional cell types in AD. Even if the present proposal about the predominant targeting of $4 \mathrm{EC} \mathrm{in} \mathrm{AD}$ does not survive experimental testing, it casts doubt on the ability to postulate targeting mechanisms based exclusively on neuronal vs. glial phenotypes. Thus, it is also possible that it is not specific cell types, but key attributes shared between neuronal and non-neuronal cells that are targeted early on in the disease process, if this process attacks first - or in any way selectively - neural cells.

\section{IMPLICATIONS OF THE FOURTH ELEMENT TARGETING HYPOTHESIS TO CONOUERING THE INNOVATION GAP AND TRANSLATIONAL APPLICATIONS TO THE PREVENTION AND TREATMENT OF AD}

Progress in conquering $\mathrm{AD}$ and related disorders is hampered by the so-called Innovation Gap (IG), which is a collection of challenges that includes: (a) the fact that the number of approved treatments has not increased despite substantial increments in the investment toward the discovery and testing for this purpose over decades, (b) the frequent lack of predictive power for the efficacy in humans of the outcomes of testing in so-called "models" of the disorder, and (c) the failure of all trials published to date based on the overwhelmingly dominant amyloid hypothesis of $\mathrm{AD}$ pathogenesis (Kuljiš, 2009b, 2010a). If the 4EC hypothesis is correct, it would open an essentially unexplored avenue for research and treatment development that could have a powerful effect in overcoming the IG.

A recent report provides powerful evidence that it may now possible to predict the outcome of patients at risk of developing $\mathrm{AD}$, by measuring putative markers of the disorder that include $\beta$-amyloid and both total and phosphorylated tau protein in the cerebrospinal fluid (De Meyer et al., 2010). However, markers with proven diagnostic value do not presently include indicators of inflammation, macroglial alterations, and, much less, 4EC involvement, although there are numerous reports suggesting - but not proving - that the former may also be of diagnostic value (Crols et al., 1986; Wallin et al., 1996; Fukuyama et al., 2001; Peskind et al., 2001; Petzold et al., 2003). Given the probable multifactorial nature of sADs (Fernández et al., 2008), it is likely that an array of markers addressing different mechanisms involved in the condition may help to: (1) increase the sensitivity and specificity of the tests under development, (2) discern subtypes of patients in which different mechanisms mediate cognitive impairment, and (3) predict and monitor the response to various alternative mechanism-selective treatments. Therefore, whether the hypothetical 4EC mechanism proposed here is universal, or unique to certain groups of patients, research aimed at testing this hypothesis may lead to the implementation of assays for 4EC involvement by cerebrospinal fluid analysis, or blood-borne indicators of 4EC involvement, or in vivo imaging assessment of such involvement (with ligands for 4EC) - or a combination of these as well as a more refined histopathological assessment for patients with Mild Cognitive Impairment and dementia postmortem. The above considerations are relevant also to our recent assessment of the intersection of the epidemics of dementia and diabetes, since this is one additional situation in which the elucidation of the targeted vs. spared or disease-resistant elements is essential to move beyond conflicting interpretations of the same or closely related experimental observations (Kuljiš and Šalković-Petrišić, 2010).

It has not escaped our attention that casting hypotheses on the primary targeting mechanisms causing $\mathrm{AD}$ in terms of one or another cell type - or cellular component, such as synapses may be narrow-minded and ultimately inadequate. In fact, given the: (1) seemingly "unconventional" nature of $4 \mathrm{EC}$, which share cytological and molecular features with neurons, macroglia, and oligodendrocytes, (2) the evidence that markers previously felt to be unique to neurons - such as doublecortin - or macroglia - such as $\mathrm{S100B}$ - are expressed by a variety of other cell types (Steiner et al., 2007; Verwer et al., 2007), and (3) that the S100B/RAGEmediated activation of microglia (Bianchi et al., 2010) indicates there may be and inextricable interaction between $4 \mathrm{EC}$, macroand microglia in the genesis of brain inflammation that initially triggers neurodegeneration (Fernández et al., 2008; Rojo et al., 2009; Eikelenboom et al., 2010; Heneka et al., 2010), it may be difficult to discern between a primary/initial macro- vs. microglial trigger of $\mathrm{AD}$. This challenge is in fact compounded by the $4 \mathrm{EC}$ hypothesis, since $4 \mathrm{EC}$ share properties with several neural cell types. However, it would seem that casting the present hypothesis in terms of a putative primary involvement of $4 \mathrm{EC}$ is scientifically testable, and provides a heuristically useful counterbalance to the presently massive - if appropriate - attention to the suspected role of microglia in the early mechanisms mediating AD (Fernández et al., 2008; Leung et al., 2009; Rojo et al., 2009; Streit et al., 2009; Ager et al., 2010). This will require further characterization of 4EC in both the normal and diseased human and non-human brain, to approach the level of sophistication with which it is possible to study today the involvement of more "conventional" types of cell in the brain and other organs. None of the above hypothetical scenarios are contradictory or incompatible with the eventual (i.e., secondary) dysfunction, followed by the degeneration and death of neurons, as the final mediator of the clinical manifestations of $\mathrm{AD}$ and related disorders as proposed by most prior authors, including ourselves (Fernández et al., 2008; Kuljiš, 2009a,b, 2010b; Rojo et al., 2009; Kuljiš and Šalković-Petrišić, 2010). Such secondary events include also inflammation and the (intra- and extracellular) accumulation of pathological forms of amyloid and tau proteins, regardless of whether these are cast as disease-compounding, or ultimately ineffective or counterproductive attempts at cellular and molecular defense.

\section{ACKNOWLEDGMENTS}

The author is grateful to Harvey J. Karten, M.D., both for criticism of an early version of the manuscript, as well as for an earlier, seminal discussion in which he forced the author to reassess 
the fact that the primary cellular target(s) of Alzheimer's disease is (are) unknown. It was this basic insight that led to this hypothesis, as part of the quest to determine the array of possible primary targets in neurodegenerative disorders, and their correlates at different levels of both conceptual and empirical analysis. The authors' work on the topics discussed herein was supported by the Brain-Mind Project, the United Through

\section{REFERENCES}

Ager, R. R., Fonseca, M. I., Chu, S. H., Sanderson, S. D., Taylor, S. M., Woodruff, T. M., and Tenner, A. J. (2010). Microglial C5aR (CD88) expression correlates with amyloidbeta deposition in murine models of Alzheimer's disease. J. Neurochem. 113, 389-401.

Alzheimer, A. (1906). "Über eine eigenartige Erkrankung der Hinrinde," in Allgemenine Zeitschrift für Psychiatrie und Psychisch-Gerichtliche Medizin, Vol. LXIV, eds E. Schultze and O. Snell (Berlin: Reimer, G), 146-148.

Alzheimer, A. (1907). "A singular disorder that affects the cerebral cortex," Neurologic Classics in Modern Translation, eds C. N. Hochberg and F. H. Hochberg (New York: Hafner Press), 41-43.

Arendt, T. (2009). Synaptic degeneration in Alzheimer's disease. Acta Neuropathol. 118, 167-179.

Bayer, T. A., and Wirths, O. (2010). Intracellular accumulation of amyloidbeta - a predictor for synaptic dysfunction and neuron loss in Alzheimer's disease. Front. Aging Neurosci. 2:8. doi: 10.3389/fnagi.2010.00008.

Beach, T. G., Walker, R., and McGeer, E. G. (1989). Patterns of gliosis in Alzheimer's disease and aging cerebrum. Glia 2, 420-436.

Bell, K. F., and Cuello, C. (2006). Altered synaptic function in Alzheimer's diseases. Eur. J. Pharmacol. 545, 11-21.

Bergles, D. E., Jabs, R., and Steinhäuser, C. (2010). Neuron-glia synapses in the brain. Brain Res. Rev. 63, 130-137.

Bergles, D. E., Roberrts, J. D. B., Somogyi, P., and Jahr, C. E. (2000). Glutamatergic synapses on oligodendrocyte precursor cells in hippocampus. Nature 405, 187-191.

Bianchi, R., Giambanco, I., and Donato, R. (2010). S100B/RAGE-dependent activation of microglia via NF- $\mathrm{KB}$ and AP-1 co-regulation of COX-2 expression by S100B, IL- $1 \beta$ and TNF- $\alpha$. Neurobiol. Aging 31, 665-677.

Crols, R., Saerens, J., Noppe, M., and Lowenthal, A. (1986). Increased GFAP levels in CSF as a marker of organicity in patients with Alzheimer's disease and other types of irreversible chronic organic brain syndrome. J. Neurol. 233, 157-160.
De Kosky, S. T., and Scheff, S. W. (1990). Synapse loss in frontal cortex biopsies in Alzheimer's disease: correlation with cognitive severity. Ann. Neurol. 27, 457-464.

De Meyer, G., Shapiro, F., Vanderstichele, H., Vanmechelen, E., Engelborghs, S., De Deyn, P. P., Coart, E., Hansson, O., Minthon, L., Zetterberg, H., Blennow, K., Shawm, L., and Trojanowski, J. Q. (2010). Diagnosis-independent Alzheimer disease biomarker signature in cognitively normal elderly people. Arch. Neurol. 67, 949-956.

Eikelenboom, P., van Exel, E., Hoozemans, J. J., Veerhuis, R., Rozemuller, A. J., and van Gool, W. A. (2010). Neuroinflammation - an early event in both the history and pathogenesis of Alzheimer's disease. Neurodeg. Dis. 7, 38-41. Maccioni, R. B. (2008). The damage signals hypothesis of Alzheimer's disease. J. Alzheimers Dis. 14, 329-333.

Fukuyama, R., Izumoto, T., and Fushiki, S. (2001). The cerebrospinal fluid level of glial fibrillary acidic protein is increased in cerebrospinal fluid from Alzheimer's disease patients and correlates with severity of dementia. Eur. Neurol. 46, 35-38.

Gleckman, A. M., Jiang, Z., Liu, Y., and Smith, T.W. (1999). Neuronal and glial DNA fragmentation in Pick's disease. Acta Neuropathol. (Berl.) 98, 55-61.

Heneka, M. T., O’Banion, M. K., Terwel, D., and Kummer, M. P. (2010). Neuroinflammatory processes in Alzheimer's disease. J. Neural. Transm. 117, 919-947.

Johnstone, M., Gearing, A. J. H., and Miller, K. M. (1999). A central role for astrocytes in the inflammatory response to $\beta$-amyloid; chemokines, cytokines and reactive oxygen species are produced. J. Neuroimmunol. 93, 182-193. J. P., Miller, D. B., Petrovich, H., Burchfield, C. M., Sharp, D. S., Markesberry, W. R., Davis, D. G., Hardman, J., Nelson, J., and White, L. R. (2004). Association of cortical astrogliosis with cognitive performance and dementia status. J. Alzheimers Dis. 6, 595-604.
Fernández, J., Rojo, L., Kuljiš, R. O., and

Kashon, M. L., Ross, G. W., O'Callaghan,

Knowledge Fund's Research Cooperability Program, the Croatian Ministry of Science, Education and Sport (MZOS 108-10800030020, M. Šalković-Petrišić, Principal Investigator) and received prior support from the Public Health Service (grant NS 29856, Rodrigo O. Kuljiš) and United States Department of Veterans Affairs (grant 5065.01 and Special Emphasis Program grant, Rodrigo O. Kuljiš).

Kuljiš, R. O. (2009a). Toward a multi-dimensional formulation of the pathogenesis and pathophysiology of the Alzheimer dementia-like syndrome applicable to a variety of degenerative disorders and normal cognition. Med. Hypotheses 73, 315-318.

Kuljiš, R. O. (2009b). "Selective cerebrocortical regional, laminar, modular and cellular vulnerability and sparing in Alzheimer's disease: unexploited clues to pathogenesis, pathophysiology, molecular- and systems-level hypothesis generation and testing," in Current Hypotheses and Research Milestones in Alzheimer's Disease, eds R. B. Maccioni and G. Perry (New York/Heidelberg: Springer Science and Business Media), 191-204.

Kuljiš, R. O. (2010a). Grand Challenges in Dementia 2010. Front. Neur. 1:4. doi: 10.3389/fneur.2010.00004.

Kuljiš, R. O. (2010b). Integrative understanding of emergent brain properties, quantum brain hypotheses and connectome alterations in dementia are key challenges to conquer Alzheimer's disease.Front. Neur. 1:15. doi: 10.3389/ fneur.2010.00015.

Kuljiš, R. O., and Šalković-Petrišić, M. (2010). Dementia, diabetes, Alzheimer's disease and insulin resistance in the brain: progress, dilemmas and new opportunities to tackle intersecting epidemics. J. Alzheimers Dis. (in press)

Leung, E., Guo, L., Bu, J., Maloof, M., El Khoury, J., and Geula, C. (2009). Microglia activation mediates fibrillar amyloid- $\beta$ toxicity in the aged primate cortex. Neurobiol. Aging. doi: 10.1016/j. neurobiolaging.2009.02.025.

Marshak, D. R., Pesce, S. A., Stanley, L. C. and Griffin, W. S. (1992). Increased S100 beta neurotrophic activity in Alzheimer's disease temporal lobe. Neurobiol. Aging 13, 1-7.

Miklossy, J., Qing, H., Radenovic, A., Kis A., Vileno, B., Làszló, F., Miller, L., Martins, R. N., Waeber, G., Mooser, V., Bosmang, F., Khalili, K., Darbinian, N. and McGeer, P.L. (2010). Beta amyloid and hyperphosphorylated tau deposits in the pancreas in type 2 diabetes. Neurobiol. Aging 31, 1503-1515.

Morgan, T. E., Rozovsky, I., Goldsmith, S. K., Stone, D. J., Yoshida, T., and Finch, C. E. (1997). Increased transcription of the astrocyte gene GFAP during middle-age is attenuated by food restriction: implications for the role of oxidative stress. Free Radic. Biol. Med. 23, 524-528.

Myung, N. H., Zhu, X., Kruman, I. I., Castellani, R. J., Petersen, R. B., Siediak, S. L., Perry, G., Smith, M. A., and Lee, H. G. (2008). Evidence of DNA damage in Alzheimer disease: phosphorylation of histone $\mathrm{H} 2 \mathrm{AX}$ in astrocytes. AGE 30, 209-215.

Naegele, R.G., D’Andrea, M. R., Lee, H., Venkataraman, V., and Wang, H. Y. (2003). Astrocytes accumulate A beta 42 and give rise to astrocytic amyloid plaques in Alzheimer disease brains. Brain Res. 971, 197-209.

Nishiyama, A., Komitova, M., Suzuki, R., and Zhu, X. (2009). Polydendrocytes (NG2 cells): multifunctional cells with lineage plasticity. Nat. Rev. Neurosci. 10, 9-22.

Nunomura, A., Castellani, R. J., Zhu, X., Moreira, P. I., Perry, G., and Smith, M. A. (2006a). Involvement of oxidative stress in Alzheimer's disease. J. Neuropathol. Exp. Neurol. 65, 631-641.

Nunomura, A., Honda, K., Takeda, A., Hirai, K., Zhu, X., Perry, G., and Smith, M. A. (2006b). Oxidative damage to RNA in neurodegenerative diseases. J. Neuropathol. Biomed. Biothechnol. 2006, 82323.

Peress, N. S., Fleit, H. B., Perillo, E., Kuljiš, R. O., and Pezullo, C. (1993). Identification of Fc $\gamma$ RI, II and III on normal human brain ramified microglia and on microglia in senile plaques in Alzheimer's disease. $J$ Neuroimmunol. 48, 71-80.

Pertusa, M., García-Matas, S., RodríguezFarre, E., Sanfeliu, C., and Cristofol, R. (2007). Astrocytes aged in vitro show a decreased neuroprotective capacity. J. Neurochem. 101, 794-805.

Perusini, G. (1910). "Über klinisch un histologisch eigenartige psychische Erkrankungen des spätern Lebensalters, " in Histologische und histopathologische Arbeiten, Vol. III, eds F. Nissl and A. Alzheimer (Jena: Fischer, G), 297-351.

Perusini, G. (1911). Sul valore nosografico di alcuni reperti istopatologici carattersitici per la senilitá. Riv. Ital. Neuropatol. Psiquiatr. Elettroter. IV, 193-213. 
Peskind, E. R., Griffin, W. S., Akama, K. T., Raskind, M. A., and Van Eldik, L. J. (2001).Cerebrospinal fluid S110B is elevated in the earlier stages of Alzheimer's disease. Neurochem. Int. 39, 409-413.

Peters, A. (2004). A fourth type of neuroglial cell in the adult central nervous system. J. Neurocytol. 33, 345-257.

Petzold, A., Jenkins, R., Watt, H. C., Green, A. J., Thompson, E. J., Keir, G., Fox, N. C., and Rossor, M. N. (2003). Cerebrospinal fluid S100B correlates with brain atrophy in Alzheimer's disease. Neurosci. Lett. 336, 167-170.

Reyners, H., de Reyners, E. G., and Maisin, J-R. (1982). The "beta astrocyte" a newly recognized radiosensitive glial cell type in the cerebral cortex. $J$. Neurocytol. 11, 967-983.

Reyners, H., de Reyners, E. G., Regniers, L., and Maisin, J.-R. (1986). A glial progenitor cell in the cerebral cortex of the adult rat. J. Neurocytol. 15, 53-61.

Rogers, J., Mastroeni, D., Leonard, B., Joyce, J., and Grover, A. (2007). Neuroinflammation in Alzheimer's disease and Parkinson's disease: are microglia pathogenic in either disorder? Int. Rev. Neurobiol. 82, 235-246.

Rojo, L. E., Fernández, J., Jiménez, J., Maccioni, A. A., Sekler, A., Kuljiš, R. O., and Maccioni, R. B. (2009). "Central nervous system inflammation and cholesterol metabolism alterations in the pathogenesis of Alzheimer's disease and diagnosis of Alzheimer's disease," in Current Hypotheses and Research Milestones in Alzheimer's Disease, eds R. B. Maccioni and G. Perry (New York/Heidelberg: Springer Science and Business Media), 125-138.

Sastre, M., Klockgether, T., and Heneka, M. T. (2006). Contribution of inflammatory processes to Alzheimer's disease: molecular mechanisms. Int. J. Dev. Neurosci. 24, 167-176.

Selinfreund, R. H., Barger, S. W., Pledger, W. J., and Van Eldik, L. J. (1991). Neurotrophic protein $\mathrm{S} 100$ beta stimulates glial cell proliferation. Proc. Natl. Acad. Sci. U.S.A. 88, 3554-3558.

Sheng, J. G., Mrak, R. E., and Griffin, W. S. (1994). S100 beta protein expression in Alzheimer's disease: potential role in the pathogenesis of neuritic plaques. Neurobiol. Aging 22, 915-922.

Simpson, J. E., Ince, P. G., Lace, G., Forster, G., Shaw, P. J., Matthews, F., Savva, G., Brayne, C., and Wharton, S. B. (2010). Astrocyte phenotype in relation to Alzheimer-type pathology in the ageing brain. Neurobiol. Aging 31, 578-590.

Steiner, J., Bernstein, H. G., Bielau, H., Berndt, A., Brisch, R., Mawrin, C., Keilhoff, G., and Bogerts, B. (2007). Evidence for a wide extra-astrocytic distribution of S100B in human brain. BMC Neurosci. 8, 2.

Streit, W. J., Braak, H., Xue, Q. S., and Bechmann, I. (2009). Dystrophic (senescent) rather than activated microglial cells are associated with tau pathology and likely precede neurodegeneration in Alzheimer's disease. Acto Neuropathol. 118, 475-485.

Terry, R. D., Masliah, E., and Salmon, D. P. (1991). Physical basis of cognitive decline in Alzheimer's disease: synapse loss is the major correlate of cognitive impairment. Ann. Neurol. $41,572-580$.

Verwer, R.W.H.,Sluiter,A.A., Balesar, R.A. Baayen, J.C., Noske, D. P., Dirven, C. M. F., Wouda, J., van Dam, A. M., Lucassen, P. J., and Swaab, D. F. (2007). Mature astrocytes in the adult human neocortex express the early neuronal marker doublecortin. Brain 130, 3321-3335.

Wallin, A., Blennow, K., and Rosengren, L. E. (1996). Glial fibrillary acidic protein in the cerebrospinal fluid of patients with dementia. Dementia 7 , 267-272.

Wirths, O., Multhaup, G., and Bayer, T. A. (2004). A modified beta-amyloid hypothesis: intraneuronal accumulation of the beta-amyloid peptide - the first step of a fatal cascade. $J$. Neurochem. 91, 513-520.
Wyss-Coray, T., Loike, J.D., Brionne, T.C., Lu, E., Anankov, R., Yan, F., Silverstein, S. C., and Husemann, J. (2003). Adult mouse astrocytes degrade amyloidbeta in vitro and in situ. Nat. Med. 9 , 453-457.

Conflict of Interest Statement: The author declares that the research was conducted in the absence of any commercial or financial relationships that could be construed as a potential conflict of interest.

Received: 16 August 2010; accepted: 22 October 2010; published online: 23 November 2010.

Citation: Kuljiš RO (2010) The Fourth Element Targeting hypothesis of Alzheimer's disease pathogenesis and pathophysiology. Front. Neur. 1:144. doi: 10.3389/ fneur.2010.00144

This article was submitted to Frontiers in Dementia, a specialty of Frontiers in Neurology.

Copyright () 2010 Kuljiš. This is an open-access article subject to an exclusive license agreement between the authors and the Frontiers Research Foundation, which permits unrestricted use, distribution, and reproduction in any medium, provided the original authors and source are credited. 